\title{
Phytoconstituents from Sidastrum micranthum (A. St.-Hil.) Fryxell (Malvaceae) and antimicrobial activity of pheophytin a
}

\author{
Roosevelt Albuquerque Gomes ${ }^{1}$, Yanna Carolina Ferreira Teles ${ }^{1}$, Fillipe de Oliveira Pereira ${ }^{1}$, \\ Luis Alberto de Sousa Rodrigues ${ }^{1}$, Edeltrudes de Oliveira Lima1, Maria de Fátima Agra², \\ Maria de Fátima Vanderlei de Souza ${ }^{1, *}$
}

\author{
${ }^{1}$ Health Sciences Center, Federal University of Paraiba, João Pessoa, PB, Brazil, ${ }^{2}$ Biotechnology Center, Federal University of \\ Paraiba, João Pessoa, PB, Brazil
}

\begin{abstract}
Sidastrum micranthum (A. St.-Hil.) Fryxell, a member of the Malvaceae family, is called malva preta in Brazil. As this species is commonly used to treat bronchitis, cough, and asthma, better knowledge of its chemical compounds is important. The phytochemical study of its hexane extract, using chromatographic techniques, led to isolation of six compounds: the triterpene isoarborinol, a mixture of sitosterol and stigmasterol, sitosterol-3-O- $\beta$-D-glucopyranoside, pheophytin a, and $13^{2}$-hydroxy- $\left(13^{2}-S\right)$-pheophytin a. Structural identification of these compounds was carried out using spectroscopic methods such as IR and 1D and 2D NMR (HOMOCOSY, HMQC, HMBC, and NOESY). Compounds isolated from $S$. micranthum were screened for their in vitro antifungal and antibacterial activity against twenty fungal and bacterial standard strains. Pheophytin a exhibited antimicrobial action against all microorganisms tested.
\end{abstract}

Uniterms: Malvaceae/phytochemistry. Sidastrum micranthum/phytochemistry. Sidastrum micranthum/ antimicrobial activity/in vitro study. Pheophytins. Medicinal plants.

\begin{abstract}
Sidastrum micranthum (A. St.-Hil.) Fryxell, pertencente à família Malvaceae, é conhecida no Brasil como "malva preta". A espécie é popularmente usada contra bronquite, tosse e asma, mostrando a relevância de conhecer melhor sua composição química. O estudo fitoquímico do extrato hexânico da espécie, utilizando técnicas cromatográficas, conduziu ao isolamento de seis compostos: o triterpeno isoarborinol, mistura de sitosterol e estigmasterol, sitosterol-3-O- $\beta$-D-glicopiranosídeo, feofitina a e de $13^{2}$-hidroxi-(132-S)-feofitina a. A identificação estrutural destes compostos foi realizada com base em métodos espectroscópicos, tais como IV, RMN 1D e 2D (HOMOCOSY, HMQC, HMBC e NOESY). As substâncias isoladas de Sidastrum micranthum foram avaliadas quanto às suas atividades antimicrobianas in vitro, contra vinte cepas fúngicas e bacterianas. A feofitina a mostrou ação antimicrobiana contra todos os microrganismos testados.
\end{abstract}

Unitermos: Malvaceae/fitoquímica. Sidastrum micranthum/fitoquímica. Sidastrum micranthum/atividade antimicrobiana/estudo in vitro. Feofitinas. Plantas medicinais.

\section{INTRODUCTION}

Malvaceae is a widespread family comprising about 243 genera and 4225 species, distributed mainly in tropical areas (Costa et al., 2007). Mainly because of their anti-oxidant and anti-inflammatory activities, the natural compounds isolated from Malvaceae species are used

\footnotetext{
*Correspondence: M. F. V. Souza. Laboratório de Fitoquímica Prof. Dr. Raimundo Braz Filho. Instituto de Pesquisa em Fármacos e Medicamentos-IPeFarM, sala C-29. Universidade Federal da Paraíba, 58051-970 - João Pessoa - PB, Brazil. E-mail: mfvanderlei@1tf.ufpb.br
}

worldwide to treat such diseases as asthma and gastritis, (Oliveira et al., 2012; Teles et al., 2014).

Sidastrum micranthum (A. St.-Hil.) Fryxell (Malvaceae), known as malva preta, is a small shrub commonly found in Cuba, Costa Rica, Venezuela, Guyana, and Brazil (Bovini, Carvalho-Okano, Vieira, 2001). The infusion prepared from its leaves has traditionally been used to treat bronchitis, cough, and asthma. The leaves are also used as cataplasms (poultices), with hot butter and olive oil, as a moisturizing agent (Agra et al., 2007). 
Previous phytochemical studies of Sidastrum have reported the presence of steroids, triterpenes, and phenolic compounds (Cavalcante et al., 2010; Teles et al., 2015). We previously reported the isolation from $S$. micranthum of tiliroside, 4'-methoxy-5,7-dihydroxyflavone (acacetin), and 7,4'-di-O-methylisoscutellarein, as well as other phenolic compounds (Gomes et al., 2011).

The antimicrobial activity of Malvaceae species is well reported (Konaté et al., 2012; Silva et al., 2009). In recent decades, the emergence of microbial resistance to antibiotics has increased interest in exploring the potential of plant-derived antimicrobials (Silva et al., 2010). To increase our knowledge of $S$. micranthum phytoconstituents, this species was submitted to a phytochemical investigation. In addition, the antimicrobial activity of the compounds isolated was evaluated.

\section{MATERIAL AND METHODS}

\section{General procedures}

Chromatographic columns were packed with silica gel 60 (ASTM, 230-400 mesh, Merck). Thin-layer chromatography (TLC) was performed on $\mathrm{PF}_{254}$ plates, and the spots were visualized under ultraviolet light (244 and $366 \mathrm{~nm}$ ) and by exposure to iodine vapor. Isolated compounds were identified by infrared (IR; Perkin-Elmer, FT-IR-1750, and Shimadzu, IR prestige 21) and extensive one- and two-dimensional nuclear magnetic resonance (NMR) analysis ( ${ }^{1} \mathrm{H} 200 \mathrm{MHz}$ and ${ }^{13} \mathrm{C} 50 \mathrm{MHz}$, VarianMercury; or ${ }^{1} \mathrm{H} 500 \mathrm{MHz}$ and ${ }^{13} \mathrm{C} 125 \mathrm{MHz}$, Bruker-AC) using deuterated solvents.

\section{Plant material}

The aerial parts of $S$. micranthum were collected in Monteiro City, Paraiba/Brazil, in June 2006. A voucher specimen (JPB 6865) was authenticated and deposited at the Professor Lauro Pires Xavier Herbarium, Federal University of Paraiba (CCEN/JPB/UFPB).

\section{Extraction and isolation of compounds}

Plant material was dehydrated in an oven at $40{ }^{\circ} \mathrm{C}$ for 72 hours and then ground with a mechanical mill, yielding $6 \mathrm{~kg}$ of powder, which was macerated with $95 \%$ ethanol at room temperature. This process was repeated to maximize the extraction. The ethanolic extract was concentrated using a rotary evaporator, yielding $200 \mathrm{~g}$ of crude ethanol extract. This material was solubilized in ethanol:water $(8: 2)$ and submitted to liquid-liquid extraction with hexane, chloroform, ethyl acetate, and $n$-butanol, affording $46 \mathrm{~g}$ of hexane extract, $7 \mathrm{~g}$ of chloroform extract, $6 \mathrm{~g}$ of ethyl acetate extract, and $8 \mathrm{~g}$ of $n$-butanol extract.

Hexane extract $(10 \mathrm{~g})$ was chromatographed on silica gel (column A) eluted with hexane, ethyl acetate, and methanol. From this process, 139 fractions were obtained and combined by TLC. Compound 1 was the pure white powder (15 mg) from fractions 29-34. Recrystallization of fractions 39-64 with chloroform yielded $79 \mathrm{mg}$ of colorless crystals, later identified as a mixture of compounds 2 and 3. Fractions 65-90 (400 mg) were chromatographed on a silica gel column under medium-pressure liquid chromatography (MPLC-Model BÜCHI 688), using hexane, ethyl acetate, and methanol and yielding 90 fractions. The pure fractions $60-64(40 \mathrm{mg})$ and 71-83 (30 mg), both amorphous dark green solids, were named compounds $\mathbf{4}$ and $\mathbf{5}$, respectively. The combined fractions 95-129, from column A, yielded a white solid precipitated (48 $\mathrm{mg}$ ) that was separated and identified as the compound 6 (Figure 1).

To identify the compounds isolated, the fractions were analyzed by IR, ${ }^{1} \mathrm{H}$ and ${ }^{13} \mathrm{C}$ NMR, and twodimensional techniques (HMQC, HMBC, COSY, and NOESY).

$\beta$-Isoarborinol (1). ${ }^{1} \mathrm{H} \mathrm{NMR}\left(\delta, \mathrm{CDCl}_{3}, 500 \mathrm{MHz}\right)$ : $5.20(\mathrm{~d}, J=6.5 \mathrm{~Hz}, \mathrm{H}-11), 3.19(\mathrm{dd}, J=4.5$ and $11.25 \mathrm{~Hz}$, H-3), 1.01 (s, H-25), 0.96 (s, H-23), 0.88 (d, H-30), 0.80 (s, H-26), 0.79 (s, H-24), 0.79 (d, H-29), 0.75 (s, H-27), 0.74 (s, H-28). ${ }^{13} \mathrm{C}$ NMR $\left(\delta, \mathrm{CDCl}_{3} 125 \mathrm{MHz}\right): 148.89$ (C-9), 114.35 (C-11), 78.97 (C-3), 59.68 (C-21), 52.38 (C-5), 52.09 (C-18), 42.87 (C-17), 41.01 (C-8), 39.66 (C-10), 39.08 (C-4), 38.21 (C-14), 36.81 (C-13), 36.10 (C-1), 36.04 (C-12), 35.96 (C-16), 30.76 (C-22), 29.67 (C-15), 28.23 (C-23), 28.21 (C-20), 27.85 (C-2), 26.70 (C-7), 22.97 (C-29), 22.14 (C-25 and C-30), 21.45 (C-6), 20.18 (C-19), 17.02 (C-26), 15.30 (C-24 and C-27), 13.99 (C-28). The ${ }^{1} \mathrm{H}-$ and ${ }^{13} \mathrm{C}-\mathrm{NMR}$ data are consistent with literature (Farruque et al., 2003).

Pheophytin a (4). ${ }^{1} \mathrm{H}$ NMR $\left(\delta, \mathrm{CDCl}_{3}, 500 \mathrm{MHz}\right)$ : 9.51 (s, H-10), 9.35 (s, H-5), 8.60 (s, H-20), 7.95 (dd, $J=$ 17.85 and $\left.11.48 \mathrm{~Hz}, \mathrm{H}-3^{1}\right) 6.30\left(\mathrm{~s}, \mathrm{H}-13^{2}\right), 6.27$ (trans, d, $\left.J=17.95 \mathrm{~Hz}, \mathrm{H}-3^{2}\right)$ and $6.18\left(\mathrm{cis}, \mathrm{d}, J=11.10 \mathrm{~Hz}, \mathrm{H}-3^{2}\right)$, 4.34 (m, H-18), 4.15 (m, H-17), 3.91 (s, H-13'), 3.69 (s, H-12 ${ }^{1}$ ), 3.63 (m, H-8 $), 3.39$ (s, H-2 $), 3.19$ (s, H-7 $), 1.84$ $\left(\mathrm{d}, \mathrm{H}-18^{1}\right), 1.66\left(\mathrm{~m}, \mathrm{H}-8^{2}\right) .{ }^{13} \mathrm{C} \mathrm{NMR}\left(\delta, \mathrm{CDCl}_{3}, 125 \mathrm{MHz}\right)$ : $189.81\left(\mathrm{C}-13^{1}\right), 173.18\left(\mathrm{C}-17^{3}\right), 172.63(\mathrm{C}-19), 169.77$ (C133), 161.19 (C-16), 155.55 (C-6), 150.92 (C-9), 149.59 (C-14), 145.25 (C-8), 142.34 (C-1), 138.14 (C-11), 136.82 (C-3), 136.51 (C-4), 136.14 (C-7), 131.1 (C-2), 129.19 (C- 
$\left.3^{1}\right), 129.14(\mathrm{C}-13), 129.03(\mathrm{C}-12), 123.11\left(\mathrm{C}-3^{2}\right), 105.10$ (C-15), 104.59 (C-10), 97.66 (C-5), 93.72 (C-20), 64.9 $\left(\mathrm{C}-13^{2}\right), 53.07\left(\mathrm{C}-13^{4}\right), 51.42(\mathrm{C}-17), 50.36(\mathrm{C}-18), 31.42$ $\left(\mathrm{C}-17^{2}\right), 29.89\left(\mathrm{C}-17^{1}\right), 23.28\left(\mathrm{C}-18^{1}\right), 19.60\left(\mathrm{C}-8^{1}\right), 17.52$ $\left(\mathrm{C}-8^{2}\right), 12.32\left(\mathrm{C}-12^{1}\right), 12.26\left(\mathrm{C}-2^{1}\right), 11.35\left(\mathrm{C}-7^{1}\right)$. The ${ }^{1} \mathrm{H}-$ and ${ }^{13} \mathrm{C}-\mathrm{NMR}$ data are consistent with the literature (Chaves et al., 2013).

$13^{2}$-Hydroxy-(132-S)-pheophytin a (5). ${ }^{1} \mathrm{H}$ NMR $(\delta$, $\left.\mathrm{CDCl}_{3}, 500 \mathrm{MHz}\right): 9.46$ (s, H-10), $9.58(\mathrm{~s}, \mathrm{H}-5), 8.60$ (s, $\mathrm{H}-20), 8.01$ (dd, $\left.J=18.0 \mathrm{~Hz}, 11.5 \mathrm{~Hz}, \mathrm{H}-3^{1}\right), 6.28$ (trans) $\left(\mathrm{d}, J=18.0 \mathrm{~Hz}, \mathrm{H}-3^{2}\right)$ and $6.17($ cis $)\left(\mathrm{d}, J=11.5 \mathrm{~Hz}, \mathrm{H}-3^{2}\right)$, 4.55 (m, H-18), 4.15 (m, H-17), 3.88 (s, H-134), 3.60 (s, H-12 ${ }^{1}$ ), 3.71 (s, H-8 ${ }^{1}$ ), 3.46 (s, H-2 ${ }^{1}$ ), 3.22 (s, H-7 $\left.{ }^{1}\right), 1.65$ $\left(\mathrm{d}, \mathrm{H}-18^{1}\right), 1.68\left(\mathrm{t}, \mathrm{H}-8^{2}\right) .{ }^{13} \mathrm{C} \mathrm{NMR}\left(\delta, \mathrm{CDCl}_{3}, 125 \mathrm{MHz}\right)$ : $192.01\left(\mathrm{C}-13^{1}\right), 172.78\left(\mathrm{C}-17^{3}\right), 172.43(\mathrm{C}-19), 173.56(\mathrm{C}-$ 133), 162.51 (C-16), 155.35 (C-6), 151.06 (C-9), 149.88 (C-14), 145.21 (C-8), 142.04 (C-1), 137.85 (C-11), 137.0 (C-3), 136.32 (C-4), 136.25 (C-7), 131.74 (C-2), 129.1 (C$\left.3^{1}\right), 129.70$ (C-13), 129.40 (C-12), $122.82\left(\mathrm{C}-3^{2}\right), 107.71$ (C-15), 104.24 (C-10), 97.92 (C-5), 93.62 (C-20), 89.0 $\left(\mathrm{C}-13^{2}\right), 51.9\left(\mathrm{C}-13^{4}\right), 51.76(\mathrm{C}-17), 50.35(\mathrm{C}-18), 31.65$ $\left(\mathrm{C}-17^{2}\right), 29.40\left(\mathrm{C}-17^{1}\right), 23.65\left(\mathrm{C}-18^{1}\right), 19.70\left(\mathrm{C}-8^{1}\right), 17.40$ $\left(\mathrm{C}-8^{2}\right), 12.26\left(\mathrm{C}-12^{1}\right), 12.07\left(\mathrm{C}-2^{1}\right), 11.25\left(\mathrm{C}-7^{1}\right)$. The ${ }^{1} \mathrm{H}$ and ${ }^{13} \mathrm{C}$ NMR data are consistent with the literature (Teles et al., 2014).

\section{Antimicrobial activity assay}

\section{Test-microorganisms}

Among the strains (bacteria and yeast) selected for evaluation of the antimicrobial activity of the isolated compounds, six were obtained from the Mycology Laboratory of the Pharmaceutical Sciences Department collection, Universidade Federal da Paraiba (LM-UFPB): Salmonella flexineri (LM 412), Candida albicans (LM 142V), Candida tropicalis (LM 028), Candida krusei (LM 12), Candida gulliermondii (LM 2101), and Candida guilliermondii (LM 011). Twelve standard strains are from the American Type Culture Collection (ATCC): Staphylococcus aureus (ATCC 6538), S. aureus (ATCC 25923), Staphylococcus epidermidis (ATCC 12228), Bacillus subtilis (ATCC 6633), Pseudomonas aeruginosa (ATCC 25853), P. aeruginosa (ATCC 9027), Escherichia coli (classic C), E. coli (ATCC 18739), E. coli (ATCC 8733), C. albicans (ATCC 90028), C. albicans (ATCC 76615), Candida tropicalis (ATCC 13803), and Candida krusei (ATCC 6258). One strain was obtained from the Institute of Biomedical Sciences, Universidade de São Paulo (ICB-USP/SP): C. albicans (ICB 12).

\section{Determination of minimum inhibitory concentration (MIC)}

Chloramphenicol and ketoconazole (Sigma-Aldrich) were used as reference antibacterial and antimycotic controls. Antifungal and antibacterial activities were determined using microbroth dilution assays in 96-well microplates, in duplicate.

Stock bacterial strains were maintained in Muller Hinton agar (MHA), and the yeast, on Sabouraud dextrose agar (SDA), under refrigeration $\left(8^{\circ} \mathrm{C}\right)$. Microorganism inocula were prepared and standardized in sterilized saline $(0.85 \%)$ containing Tween $80(1 \%)$. Turbidity was adjusted to a $0.5 \mathrm{McF}$ arland tube to obtain an inoculum of $10^{6}$ colony-forming units $\left.(\mathrm{CFU}) / \mathrm{mL}\right)$. Minimum inhibitory concentrations (MICs) were determined with the microdilution method using 96-well plates (INLAB) (Hadacek, Greger, 2000).

To each well was added $100 \mu \mathrm{L}$ of doubleconcentrated liquid medium CSD or HCM. Ten microliters of each compound was then added to the wells of the first row of the plate, and by serial dilution, concentrations from 300 to $9 \mu \mathrm{g} / \mathrm{mL}$ were obtained. Later, $10 \mu \mathrm{L}$ of the microorganism inoculum was added to the wells. The plate was incubated at $35^{\circ} \mathrm{C}$ for $24 \mathrm{~h}$. Afterward, $20 \mu \mathrm{L}$ of resazurin sodium $0.01 \%(\mathrm{w} / \mathrm{v})$ (Sigma-Aldrich) was added. Resazurin is a colorimetric indicator of oxidationreduction for bacteria. As an indicator for yeast, $20 \mu \mathrm{L}$ of $1 \%$ triphenyltetrazolium chloride (TTC) (Sigma-Aldrich) was used. The assay was incubated at $35^{\circ} \mathrm{C}$. Results were read by viewing the color change from blue to pink for bacteria, and from colorless to pink for yeast, indicating growth of the microorganism.

The MIC of the active compound was defined as the lowest concentration able to inhibit growth (Deswal, Chand, 1997). Compounds were considered either active or nonactive according to the following criteria: Compounds with MICs between 50 and $500 \mu \mathrm{g} / \mathrm{mL}$ were classified as having strong/great antimicrobial activity; those with MICs from 500 to $1500 \mu \mathrm{g} / \mathrm{mL}$ had moderate activity; and those with MICs higher than $1500 \mu \mathrm{g} / \mathrm{mL}$ were considered to have weak antimicrobial activity (Houghton et al., 2007; Sartoratto et al., 2004).

\section{RESULTS AND DISCUSSION}

\section{Structural elucidation of the isolated compounds}

The structural assignments of compounds $\mathbf{2 ,} \mathbf{3}$, and 6 isolated from S. micranthum (Figure 1) were made based on spectral analysis and are in good agreement with those reported in the literature. Thus, their structures were 
identified as sitosterol (2), stigmasterol (3), and sitosterol 3-O- $\beta$-D-glucopyranoside (6) (Kojima et al., 1990; Kongduang et al., 2008; Rashed et al., 2014). Steroids are widespread in plants and play an important role as components of vegetable cell walls and membranes. They have been previously been reported in many Malvaceae species, such as Sidastrum paniculatum, Wissadula periplocifolia, Sida rhombifolia, Sida galheirensis, Bakeridesia pickelli, and Herissantia crispa (Teles et al., 2015; Teles et al., 2014; Chaves et al., 2013; Silva et al., 2006; Costa et al., 2007; Costa et al., 2009).

Compound 1 , on ${ }^{1} \mathrm{H}$ NMR, exhibited a triterpene profile, characterized by six singlet methyls, two doublet methyls, one oxymethinic proton $\left(\delta_{\mathrm{H}} 3.19\right)$, and one olefinic proton $\left(\delta_{\mathrm{H}} 5.20\right)$. The presence of 30 signals on ${ }^{13} \mathrm{C}$ NMR and the correlations observed on HMQC, HMBC, COSY, and NOESY spectra led to identification of compound 1 as $\beta$-isoarborinol, a hopane triterpene previously isolated from Melicope indica Wt. (Rutaceae) (Farruque et al., 2003). Triterpenes have been reported in Malvaceae species, and hopane triterpenes have recently been reported in Wissadula periplocifolia and Sidastrum paniculatum (Teles et al., 2014; Teles et al., 2015).

Compounds $\mathbf{4}$ and $\mathbf{5}$ appeared similar (dark green amorphous solids) and had similar IR bands. On the basis of ${ }^{1} \mathrm{H}$ and ${ }^{13} \mathrm{C}$ NMR spectra, we confirmed that compounds

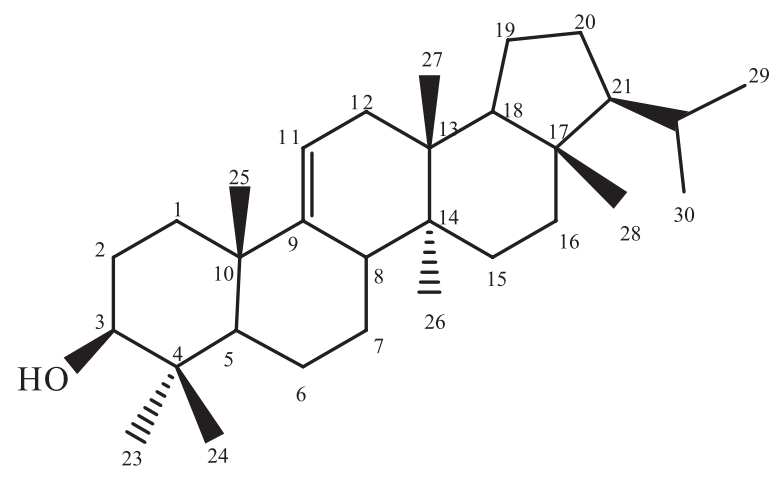

1:ß-isoarborinol

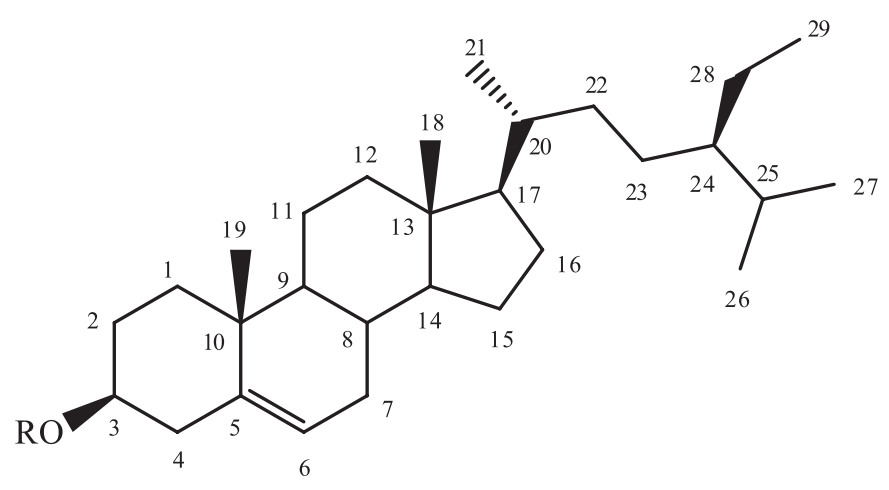

2; $\mathrm{R}=\mathrm{H}$

3: $\mathrm{R}=\mathrm{H} ; \Delta^{22,23}$

6: $R=\beta-D-G l u c o p y r a n o s y l$

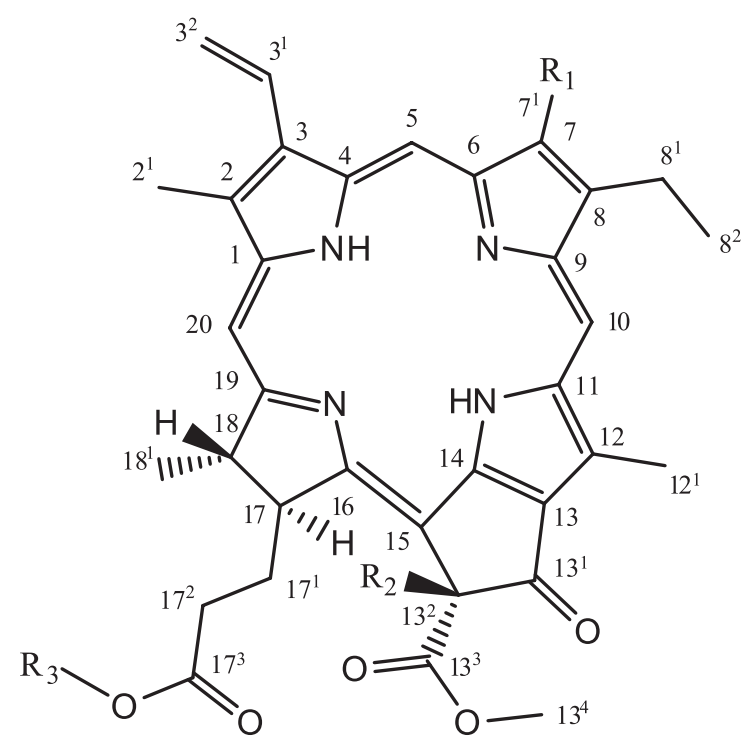

4: $\mathrm{R}_{1}=\mathrm{CH}_{3}, \mathrm{R}_{2}=\mathrm{H}, \mathrm{R}_{3}=$ phytol

5: $\mathrm{R}_{1}=\mathrm{CH}_{3}, \mathrm{R}_{2}=\mathrm{OH}, \mathrm{R}_{3}=$ phytol

FIGURE 1 - Chemical constituents isolated from Sidastrum micranthum. 
4 and 5 are structurally related, both being formed by porphyrin rings. Extensive analyses of spectral data and comparisons with the literature led to identification of compounds 4 and 5 as pheophytin a and $13^{2}$-hydroxy- $\left(13^{2}\right.$ $\mathrm{S})$-pheophytin a, respectively, previously isolated from the Malvaceae species W. periplocifolia, S. rhombifolia, and S. galheirensis (Teles et al., 2014; Chaves et al., 2013; Silva et al., 2006).

\section{Antibacterial and antifungal activities}

The isolated compounds sitosterol/stigmasterol $(\mathbf{2} / 3)$, pheophytin a (4), acacetin (7), and 7,4'-di-Omethylisoescutelarein (8) were assessed against bacteria and yeast strains. Isolation of the flavones $\mathbf{7}$ and $\mathbf{8}$ has previously been reported (Gomes et al., 2011).

The results obtained indicate that the mixture of phytosterols $\mathbf{2 / 3}$ and the flavones acacetin (7) and 7,4'-di-
$O$-methylisoescutelarein $(8)$ did not have an inhibitory effect on the test strains. In contrast, pheophytin a (4) exhibited strong antimicrobial activity against all test strains (Table I).

Two yeast (C. albicans ATCC -90028 and $C$. albicans ATCC - 76615) were sensitive to pheophytin a at $38 \mu \mathrm{g} / \mathrm{mL}$ and were the most sensitive test strains. At 75 $\mu \mathrm{g} / \mathrm{mL}$, pheophytin a was able to inhibit growth of $85 \%$ of all strains, indicating strong antimicrobial activity for this compound, according to the criteria reported by Sartoratto et al. (2004) and Houghton et al. (2007).

Pheophytins are formed by the degradation of chlorophyll by $\mathrm{Mg}$-dechelatase and chlorophyllase enzymes and have been previously been reported to have anti-leishmanial and cytotoxic activity (Hörtensteiner et al., 1998; Cheng et al., 2001; Sakata et al., 1990). The results obtained are in agreement with the antimicrobial effect of some chlorophyll derivatives, including

TABLE I - MIC values ( $\mu \mathrm{g} / \mathrm{mL})$ of compounds isolated from Sidastrum micranthum

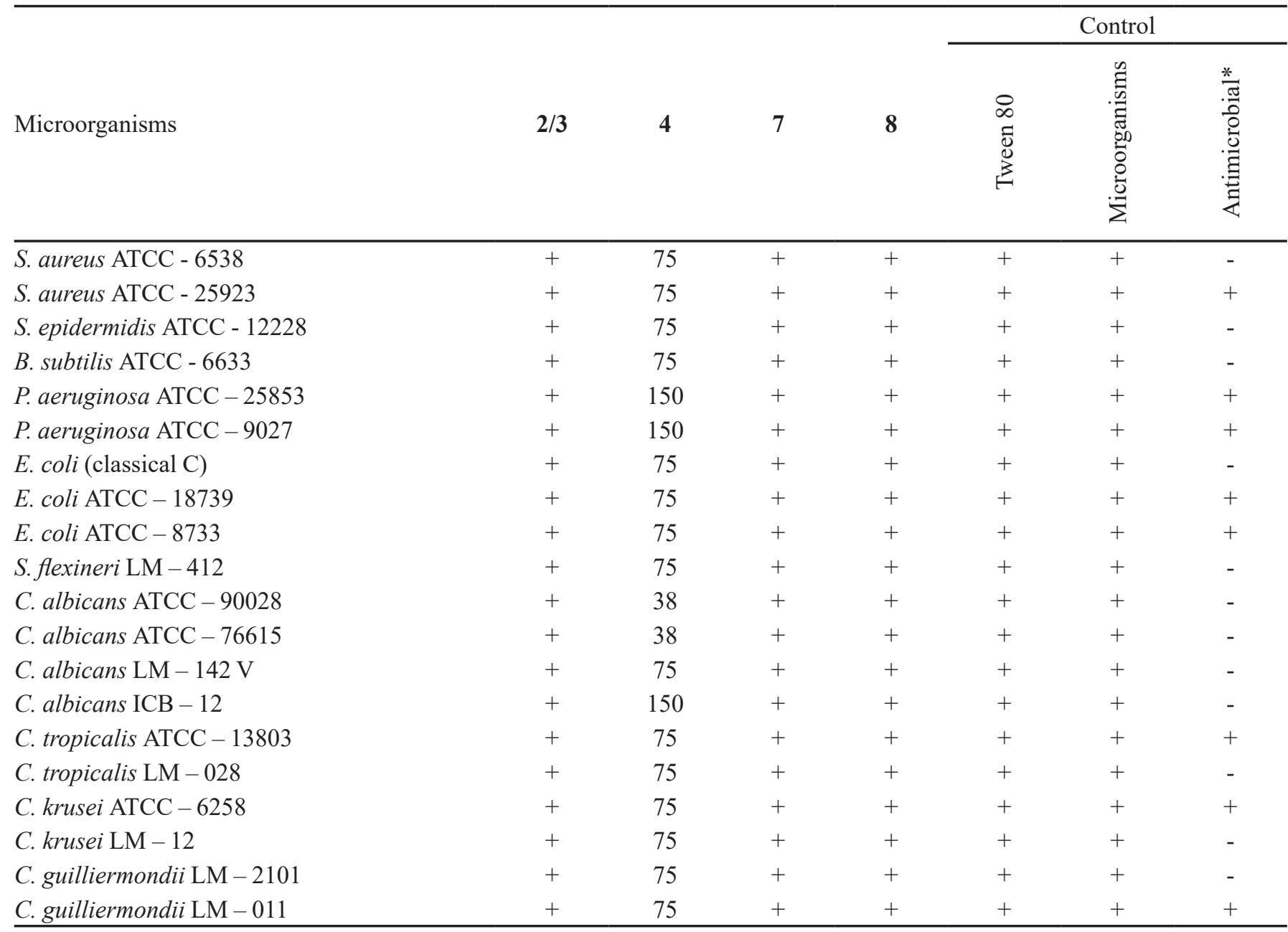

$+=$ Presence of microbial growth (compound not active), $-=$ Absence of microbial growth 
pheophorbide, as determined by Gerola et al. (2011). Thus, the antimicrobial activity shown by these compounds may be evidence of their additional role protecting plants from microorganisms in their environment.

\section{CONCLUSION}

This phytochemical study of Sidastrum micranthum hexane extract resulted in the isolation of six compounds: $\beta$-isoarborinol (1), a mixture of sitosterol (2) and stigmasterol (3), pheophytin a (4), $13^{2}$-hydroxy- $\left(13^{2}-\mathrm{S}\right)$ pheophytin a (5) and sitosterol-3-O- $\beta$-D-glucopyranoside (6). Compounds $\mathbf{1}, \mathbf{4}$, and 5 are reported here for the first time in the Sidastrum genus. In addition, pheophytin a exhibited significant antimicrobial activity against all bacteria and yeasts tested. According to the criteria reported by Sartoratto et al. (2004) and Houghton et al. (2007), pheophytin a is considered to possess strong antimicrobial activity against $C$. albicans (ATCC 90028) and C. albicans (ATCC 76615).

\section{ACKNOWLEDGMENT}

The authors thank the National Council for Scientific and Technological Development, Brazil (CNPq), and Coordenação de Aperfeiçoamento de Pessoal de Nível Superior, Brazil (CAPES) for financial support and the Multiuser Analytical Central Laboratory (LMCA-UFPB) for obtaining the spectra.

\section{REFERENCES}

AGRA, M.F.; BARACHO, G.S.; BASÍLIO, I.J.D.; NURIT, K.; COELHO, V.P.; BARBOSA, D.A. Sinopse da flora medicinal do cariri paraibano. Oecol. Bras., v.11, p.323330, 2007.

BOVINI, M.G.; CARVALHO-OKANO, R.M.; VIEIRA, M.F. Malvaceae A. Juss. no Parque Estadual do Rio Doce, Minas Gerais, Brasil. Rodriguésia, v.52, p.17-47, 2001.

CAVALCANTE, J. M. S.; NOGUEIRA, T. B. S. S.; TOMAZ, A. C. A.; SILVA, D.A.; AGRA, M. F.; CARVALHO, P.R. C.; RAMOS, S. R. R.; NASCIMENTO, S. C.; GONCALVESSILVA, T.; SOUZA, M. F. V. Steroidal and phenolic compounds from Sidastrum paniculatum (L.) Fryxell and evaluation of cytotoxic and anti-inflammatory activities. Quím. Nova, v.33, p.846-849, 2010.
CHAVES, O.S.; GOMES, R.A.; TOMAZ, A.C.; FERNANDES, M.G.; GRAÇAS MENDES, L. JR.; AGRA, M.F.; BRAGA, V.A.; SOUZA, M. F. V. Secondary metabolites from Sida rhombifolia L. (Malvaceae) and the vasorelaxant activity of cryptolepinone. Molecules, v.18, p.2769-2777, 2013.

CHENG, H.H.; WANG, H.K.; ITO, J.; BASTOW, K.F.; TACHIBANA, Y.; NAKANISHI, Y.; XU, Z.H.; LUO, T.Y; LEE, K.H. Cytotoxic pheophorbide-related compounds from Clerodendrum calamitosum and C. Crytophyllum. J. Nat. Prod., v.64, p.915-919, 2001.

COSTA, D.A.; SILVA, D.A.; CAVALCANTI, A.C.; MEDEIROS, M.A.A.; LIMA, J.T.; CAVALCANTE, J.M.S.; SILVA, B.A.; AGRA, M.F.; SOUZA, M.F.V. Chemical constituents from Bakeridesia pickelii glucopyranoside on guinea-pig ileum. Quím. Nova, v.30, p.901-903, 2007.

COSTA, D.A.; MATIAS, W.M.; LIMA, I.O.; XAVIER, A.L.; COSTA, V.B.M.; DINIZ, M.F.; AGRA, M.F.; BATISTA, L.M.; SOUZA, M.F.V.; SILVA, D.A. First secondary metabolites from Herissantia crispa L. (Brizicky) and the toxicity activity against Artemia salina Leach. Quím. Nova, v.32, p.48-50, 2009.

DESWAL, D.P.; CHAND, U. Standardization of the tetrazolium test for viability estimation in rice bean (Vigna umbellate T.) seeds. Seed Science and Technology. Seed Sci. Technol., v.25, p.409-417, 1997.

FARRUQUE, R.; CHOWDHURY, R.; SOHRAB, M.H.; HASAN,C.M.; RASHID, M.A. Triterpene constituents from the leaves of Melicope indica. Pharmazie, v.58, p.518-520, 2003.

GEROLA, A.P.; SANTANA, A.; FRANÇA, P.B.; TSUBONE, T.M.; DE OLIVEIRA, H.P.; CAETANO, W.; KIMURA, E.; HIOKA, N. Effects of metal and the phytyl chain on chlorophyll derivatives: physicochemical evaluation for photodynamic inactivation of microorganisms. Photochem. Photobiol., v.87, p.884-894, 2011.

GOMES, R.A; MACIEL, J.K.S; AGRA, M.F; SOUZA, M.F.V; FALCÃO-SILVA, V.S; SIQUEIRA-JUNIOR, J.P. Phenolic compounds from Sidastrum micranthum (A. St.-Hil.) fryxell and evaluation of acacetin and 7,4'-Di$O$-methylisoscutellarein as modulator of bacterial drug resistance. Quím. Nova, v.34, p.1385-1388, 2011. 
HADACEK, F.; GREGER, H. Testing of antifungal natural products: methodologies, comparability of results and assay choice. Phytochem. Anal., v.11, p.137-147, 2000.

HÖRTENSTEINER, S.; WÜTHRICH, K.L.; MATILE, P.; ONGANIA, K.H.; KRAUTLER, B. The key step in chlorophyll breakdown in higher plants. Cleavage of pheophorbide a macrocycle by a monooxygenase. J. Biol. Chem., v.273, p.15335-15339, 1998.

HOUGHTON, P.J.; HOWES, M.J.; LEE, C.C.; STEVENTON, G. Uses and abuses of in vitro tests in ethnopharmacology: visualizing an elephant. J. Ethnopharmacol., v.110, p.391400, 2007.

KONATÉ, K.; HILOU, A.; MAVOUNGOU, J. F.; LEPENGUÉ, A. N.; SOUZA, A.; BARRO, N.; DATTÉ, J.Y.; M'BATCHI, B.; NACOULMA, O. G. Antimicrobial activity of polyphenol-rich fractions from Sida alba L. (Malvaceae) against co-trimoxazol-resistant bacteria strains. Ann. Clin. Microbiol. Antimicrob., v.11, p.1-6, 2012.

KONGDUANG, D.; WUNGSINTAWEEKUL, J.; DEEKNAAMKUL, W. Biosynthesis of $\beta$-sitosterol and stigmasterol proceeds exclusively via the mevalonate pathway in cell suspension cultures of Croton stellatopilosus. Tetrahedron Lett., v.49, p.4067-4072, 2008.

KOJIMA, H.; SATO, N.; HATANO, A.; OGURA, H. Sterol glucosides from Prunella vulgaris. Phytochemistry, v.29, p.2351-2355, 1990.

OLIVEIRA, A. M. F.; PINHEIRO, L. S.; PEREIRA, C. K. S.; MATIAS,W. N.; GOMES, R. A.; CHAVES, O. S.; SOUZA, M. F. V.; ALMEIDA, R. N.; ASSIS, T. S. Total phenolic content and antioxidant activity of some malvaceae family species. Antioxidants, v.1, p.33-37, 2012.

RASHED, K.; CIRIC, A.; GLAMOCLIJA, J.; CALHELHA, R. C.; FERREIRA, I.C.F.R.; SOKOVIC, M. Antimicrobial and cytotoxic activities of Alnus rugosa L. aerial parts and identification of the bioactive components. Ind. Crop. Prod., v.59, p.189-196, 2014.

SAKATA, K.; YAMAMOTO, K.; ISHIKAWA, H.; YAGI, A.; ETOH, H.; INA, K. Chlorophyllone-a, a new pheophorbide-a related compound isolated from Ruditapes philippinarum as an antioxidative compound. Tetrahedron Lett., v.31, p.1165-1168, 1990.
SARTORATTO, A.; MACHADO, A.L.M.; DELARMELINA, C.; FIGUEIRA, G.M.; DUARTE, M.C.T.; REHDER, V.L.G. Composition and antimicrobial activity of essencial oils from aromatic plants used in Brazil. Braz. J. Microbiol., v.35, p.275-280, 2004.

SILVA, D.A.; SILVA, T.M.S.; LINS, A.C.S.; COSTA, D.A.; CAVALCANTE, J.M.S.; MATIAS, W.N.; SOUZA, M.F.V.; BRAZ-FILHO, R. Constituintes Químicos e atividade antioxidante de Sida galheirensis ULBR (Malvaceae). Quím. Nova, v.29, p.1250-1254, 2006.

SILVA, D.A.; FALCÃO-SILVA, V. S.; GOMES, A.Y. S.; COSTA, D.A.; LEMOS, V.S.; AGRA, M.F.; BRAZ-FILHO, R.; SIQUEIRA-JUNIOR, J.P.; SOUZA, M.F.V. Triterpenes and phenolic compounds isolated from the aerial parts of Herissantia tiubae and evaluation of 5,4',-dihydroxy3,6,7,8,3'-pentamethoxyflavone as modulator of bacterial drug resistance. Pharm. Biol., v.47, p.279-284, 2009.

SILVA, C.J; BARBOSA, L.C.A; DEMUNER, A.J; MONTANARI, R.M; PINHEIRO, A.L; DIAS, I; ANDRADE, N.J. Chemical composition and antibacterial activities from the essential oils of Myrtaceae species planted in Brazil. Quím. Nova, v.33, p.104-108, 2010.

TELES, Y.C.F.; GOMES, R.A.; OLIVEIRA, M.S.; LUCENA, K.L.; NASCIMENTO, J.S.; AGRA, M.F.; IGOLI, J.O.; GRAY, A.I.; SOUZA, M.F.V. Phytochemical investigation of Wissadula periplocifolia (L.) C. Presl and evaluation of its antibacterial activity. Quím. Nova, v.37, p.1491-1495, 2014.

TELES, Y.C.F.; CHAVES, O. S.; AGRA, M. F.; BATISTA, L.M.; QUEIROZ, A. C.; ARAÚJIO, M.V.; ALEXANDREMOREIRA, M.S.; BRAZ-FILHO' R.; SOUZA, M.F.V. Chemical constituents from Sidastrum paniculatum and evaluation of their leishmanicidal activity. Rev. Bras. Farmacog., v.25, p.363-368, 2015.

Received for publication on $22^{\text {th }}$ October 2014 Accepted for publication on $28^{\text {th }}$ July 2015 
